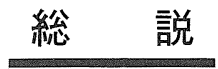

\title{
非共有結合型光誘起電子 移動研究の新展開
}

\author{
須賀 康裕・有村 隆志 \\ 工業技術院 物質工学工業技術研究所 $\mathrm{COE}$ 特別研究室 \\ （テ305-8565 茨城県つくば市東 1-1）
}
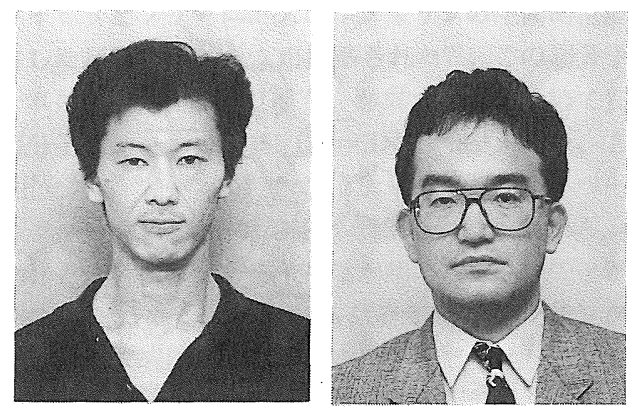

\section{New Development of Photo-induced Electron Transfer Events in Non-covalently Assemblies}

\author{
Yasuhiro Suga and Takashi ARIMURA \\ National Institute of Materials and Chemical Research, COE laboratory \\ (1-1 Higashi, Tsukuba-shi, Ibaraki-ken 305-8565)
}

\begin{abstract}
Electron-transfer (ET) reactions in metalloproteins play an important role in both photosynthesis and respiratory oxidative phosphorylation. In spite of this importance, the exact nature of specific partner-to-partner in ET processes is still poorly understood. In terms of specifics, a lot of chemists have tested the importance of three different kinds of non-covalent pathway interactions that are proposed to play a critical role in mediating biological ET events, namely : (1) van der Waals associations, (2) Electrostatic contacts, (3) Hydrogen bonds. This review summarizes the recent development of new, non-covalently approaches to ET modeling.

Key words : supramolecular assembly system, electron transfer, non-covalent bond, hydrogen bond, coordination bond, $\pi-\pi$ stacking interaction
\end{abstract}

\section{1 はじめに}

生体エネルギー変換膜では，ポルフィリン誘導体の選 択的電子伝達システムにより, 光を高効率でエネルギー に変換している。このシステムは光子をエネルギー源と しており，電荷分離効率がほぼ 100\% であるため，現時 点で広く利用されている石油エネルギーに代わる次世代 のエネルギーシステムとみなすことができる。すなわち, 生体エネルギー変換膜の電子移動反応機構を解明するこ とは，電子移動に関して分子レベルでの解釈ができるば かりでなく，光をエネルギー源とする究極の光電変換デ バイス作製のための方法論を与えると考えられる。

これまで, 光合成反応中心で起こる光誘起電子移動反 応機構を解明するために, 電子ドナー (D) - 電子アクセ プター (A) 間を共有結合で固定し，距離や配向を精緻に 制御したモデル研究が行われてきた1)。なかでも，Fig.

連絡者：有村隆志

E-mail : takashi@home.nimc.go.jp
1 に示す分子は，1つの分子上で天然光合成反応中心と 同様な電子移動過程を経て電荷分離する状態を再現した 最初の例である2)。しかしながら, 生体中の電子移動シ ステムのクロモフォア群は共有結合で固定されているわ けではなく,共有結合に比較して弱い分子間相互作用(例 えば，配位結合，芳香族化合物間で働く $\pi-\pi$ スタッキ ング，水素結合など）によって配置されている。すなわ ち，生体中では，幾つかのクロモフォアが種々の非共有 結合によって互いを認識して自己組織化し，高度に組織 制御された超分子構造において電子移動は起こる。この 超分子化学については Lehn を先駆者とした多くの化学 者によって精力的に研究されてきたが3)，超分子システ ム中での電子移動反応についての研究が注目されるよう になったのはここ 10 数年である4)。最近ますます多く の D-A 超分子システムが研究されていることを考える と, 多くの研究者が電子移動反応に対する非共有結合に よる相互作用の役割の解明に力を注いでいることが同わ れる。

本稿では，D-A 間を配位結合 $(2.1) ， \pi-\pi$ スタッキ 


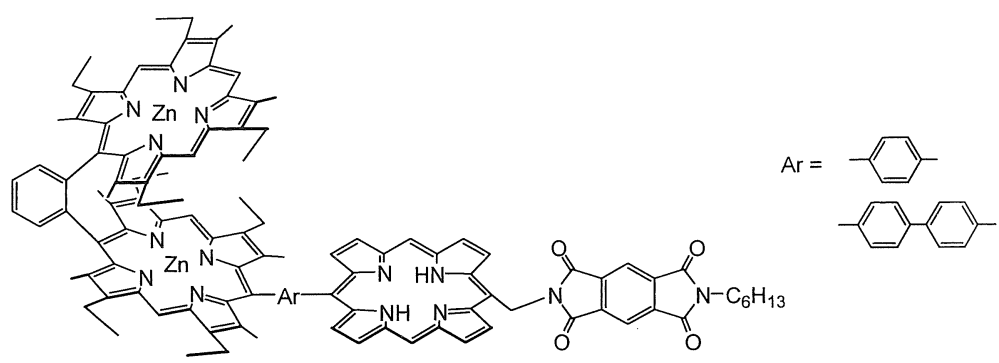

Fig. 1 Schematic Representation of Diporphyrin-Porphyrin-Pyromellitimide Triads.

ング (2.2)，静電相互作用 (2.3)，水素結合 (2.4) を 用いて配置した超分子システム中で起こる電子移動反応 についての最近の研究例を紹介する。

\section{2 電子移動反応のコントロールを目指す モデルシステム}

\section{$2 \cdot 1$ 配位結合を利用した超分子システム中での電子} 移動

配位結合は，金属と配位子の非結合電子対との間で形 成される結合であり超分子システムを構築する上で有効 に利用される。Fig. 2 に示す超分子システムは，带鉛ポ ルフィリンと金ポルフィリン間にルテニウム金属錯体を 形成させ， D-A 間をルテニウムとテルピリジンとの配 位結合によりリンクさせた系である5)。この系では，過 渡吸収スペクトル解析により励起された亜鉛ポルフィリ ンからルテニウム錯体部位へ，続いて金ポルフィリンへ と2 段階で電子移動が起こることが分かった。各々の電 子移動速度は，それぞれ $50 \mathrm{ps}$ と $1.6 \mathrm{~ns}$ と見積もられて おり，基底状態への逆電子移動速度は $33 \mathrm{~ns}$ であった。 この結果は, 電子移動反応を多段階にすることで電荷分 離状態の長寿命化を達成した共有結合系の多段階電子移 動システム ${ }^{6)}$ と同様のものである。さらに，この系では， リンカー部位の金属を任意に選択できること7)，D およ び A 部位についても任意に選択可能8)であることから，
多様な超分子システムを構築することができると考えら れる。また，カテナンおよびロタキサンを利用した D-A 超分子システムの電子移動反応についても種々検 討されている (Fig. 3) 9)。例えば，Fig.4 に示すロタキ サンを利用した $\mathrm{D}-\mathrm{A}$ 超分子システムでは，D（带鉛ポ ルフィリン)-A（金ポルフィリン）間のリンカー部位の フェナントロリンは種々の金属との錯形成が可能であ り， D-A 間の位置を金属錯体の形成の有無によって制 御することができる。例えば，リンカー部位のフェナン トロリンが錯形成していない時には D-A 間の距離はお よそ5〜7. Aであるのに対して，錯形成している場合， その距離は 12〜19 ̊ になると見積もられている。さら に興味深いのは，錯形成に使用する金属の種類によって 電子移動過程が異なり,リチウムカチオンを用いた場合, D-A 間は一段階の電子移動反応であるが，遷移金属を 用いた場合ではその遷移金属の還元を伴った多段階電子 移動反応が起こると報告されている。

一方，ピリジンがポルフィリン中心金属へ軸配位する ことを利用して，ピリジル基を有するフラーレンと亜鉛 ポルフィリンからなる超分子システムが検討されてい る ${ }^{10)}$ 。この超分子システムの電子移動反応過程について は，その電荷分離種の時間分解 EPR スペクトル解析か ら Scheme 1 に示すような電子移動反応機構が考えられ ている。同様なアイデアで Fig. 5 に示すようなナフタ

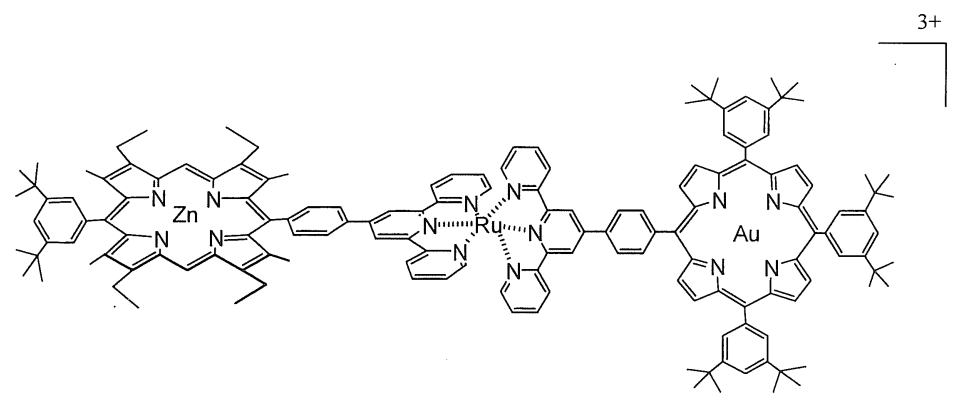

Fig. 2 Supramoleculer Assembly Having Ru Complex at the Central Position of Donor-Acceptor System. 


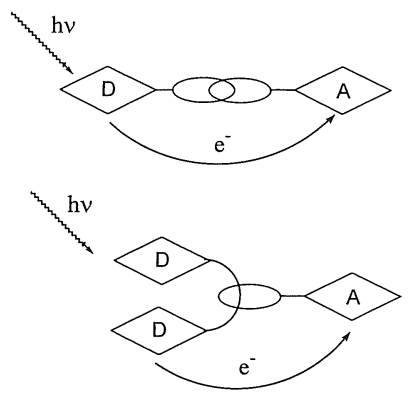

Fig. 3 Donor and Acceptor Linked Mechanically in Catenane (above), Rotaxane (below).
レンジイミドとフリーベースポルフィリンの空間的位置 を固定した超分子システムが構築された ${ }^{11)}$ 。この超分子 システムは，2ヶ所で配位結合を形成するため極めて安 定な超分子構造を形成する $\left(K_{\mathrm{a}}=3 \times 10^{8} \mathrm{dm}^{3} \mathrm{~mol}^{-1}\right)$ 。さ らに, 蛍光スペクトル測定では, ドナーであるフリーベー スポルフィリンの蛍光の $70 \%$ が消光されることから, この超分子システム中で電子移動が起こっていることが 確かめられた。また, Sakata らは亜鉛ポルフィリンダ イマーと両鎖末端にピリジル基を有するピロメリットイ ミドによる橋かけ構造を形成するような超分子システム の構築に成功した ${ }^{12)}$ 。この超分子システムにおいても, Fig. 6 に示すように 2 つの配位点で橋かけ構造体を形成
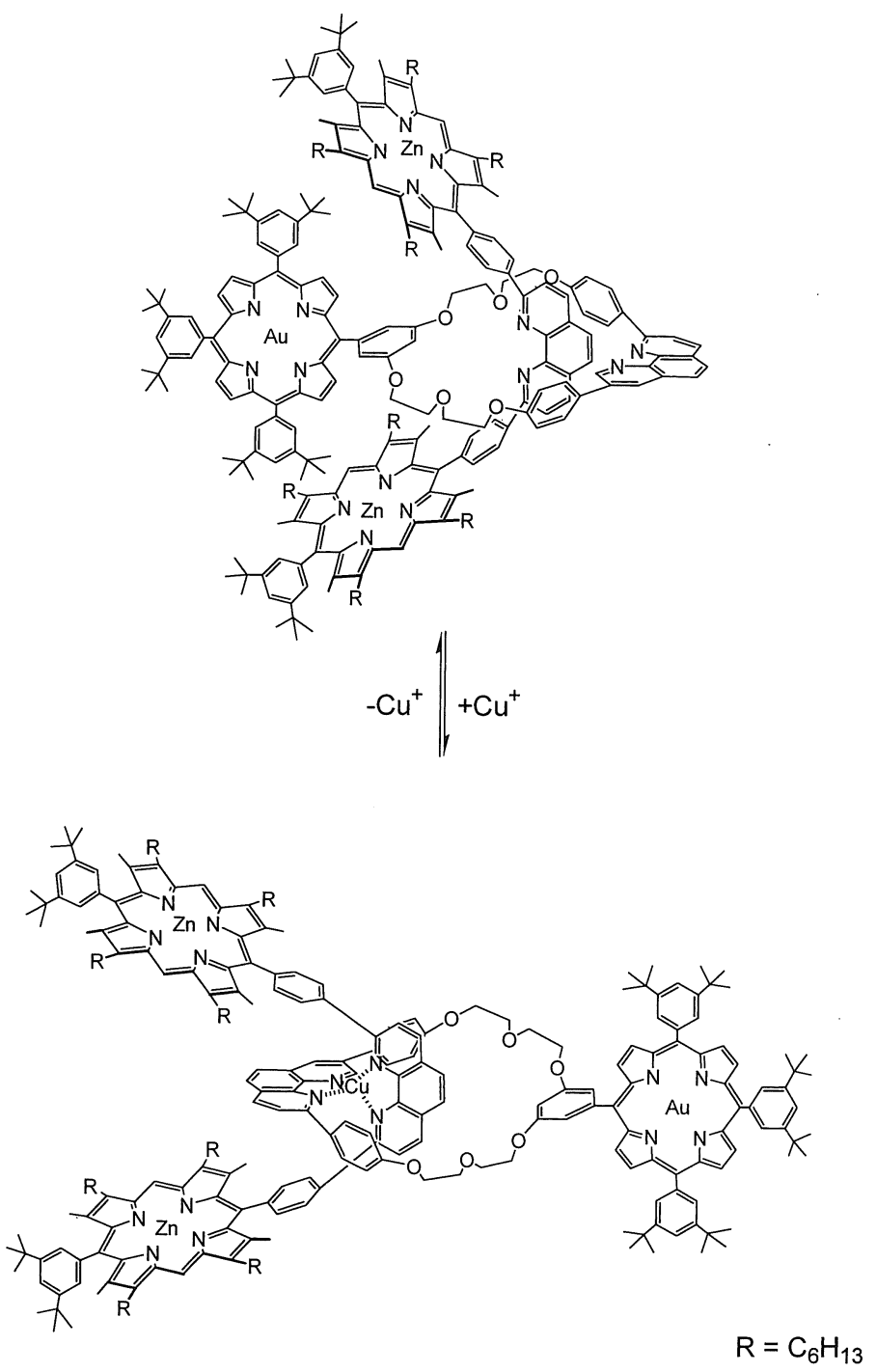

Fig. 4 Changeover of the Rotaxane in the Presence or Absence of $\mathrm{Cu}$ Cation. 

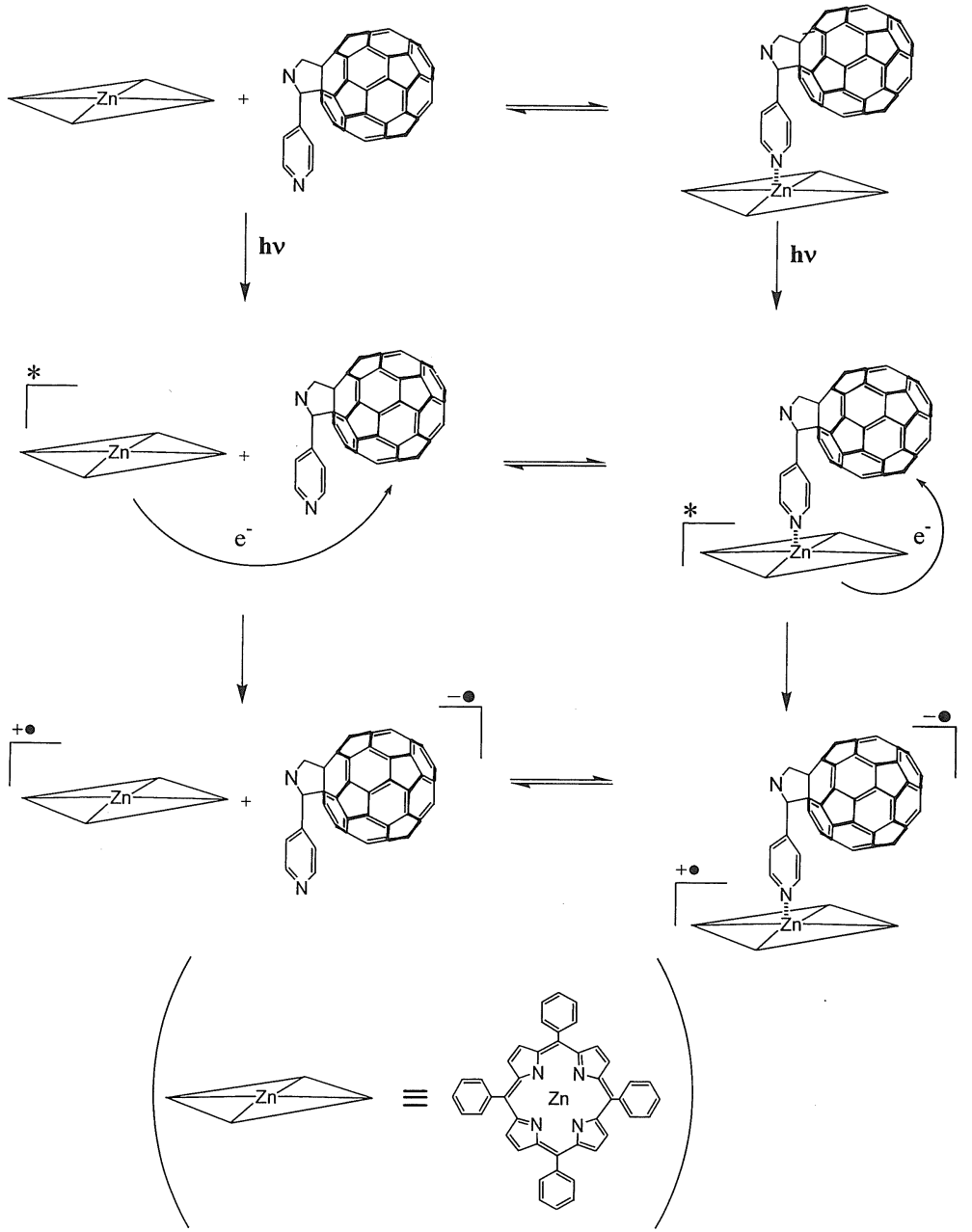

Scheme 1

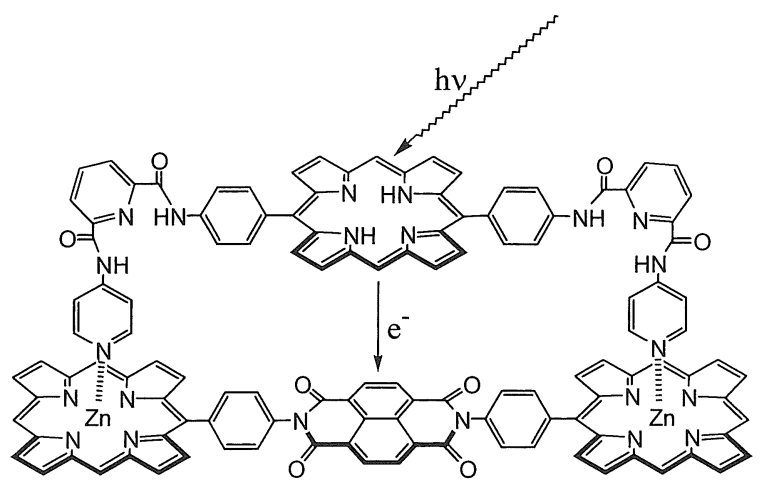

Fig. 5 Supramoleculer Assembly Connected by Two Coordination Bonds between Pyridyl Group and Zn-porphyrin. 

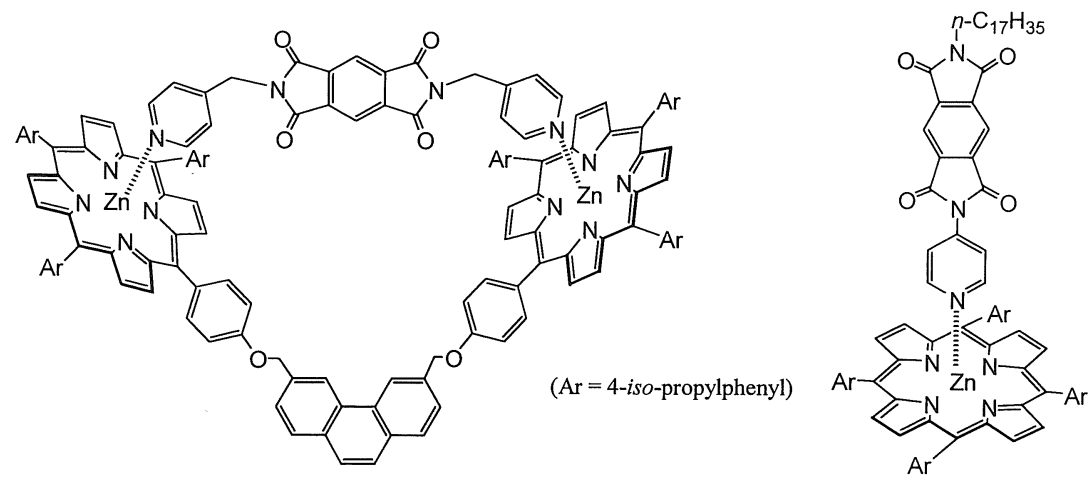

Supramolecular assembly

Fig. 6 Structures of Pyromellitimide Bridged Zn-porphyrin Dimer (left) and Its Reference Compound (right).

することから，会合定数は極めて高い值 $\left(2.6 \times 10^{6} \mathrm{dm}^{3}\right.$ $\mathrm{mol}^{-1}$ ) であった。また，この超分子システムの蛍光ス ペクトル測定では，極めて強い消光が起こることも観測 されて打り, Fig. 6 の橋かけ超分子構造が安定に保持さ れていることを示している。さらに，過渡吸収スペクト ル測定からこの系の電子移動速度はそれぞれ, 電子移動 速度 $\left(k_{\mathrm{CS}}\right)=2.1 \times 10^{10} \mathrm{~s}^{-1}$, 逆電子移動速度 $\left(k_{\mathrm{CR}}\right)=1.3$ $\times 10^{10} \mathrm{~s}^{-1}$ と見積もられている。この值は, Fig. 6 の右 に示す対照化合物の電子移動速度とほぼ同程度であった ことから，彼らは配位結合を利用した超分子構造体の場 合には，その超分子構造の違いによる電子移動への影響 はほとんどないと結論している。

ここでは，配位結合を用いた超分子システムの電子移 動について最近の研究例を紹介し, 配位結合が D-A 超 分子システムを構築する上で有効な手段であることを示 した。さらに, これらの系では錯形成の有無, 用いる金 属の種類を選択することにより電子移動過程を制御でき る可能性も示唆されている。

$2 \cdot 2$ ドナー-アクセプター間の $\pi-\pi$ スタッキング相 互作用を利用した超分子構造の形成とその電子 移動

芳香族化合物間の相互作用に見られるような, faceto-face で起こる $\pi-\pi$ スタッキングも超分子構造を形成 する際の重要なドライビングフォースとなる。

Fig. 7 に示してあるのは，ジベンゾ[34]クラウンエー テルの空孔に $N, N$-ジメチル-2,7-ジアザピレニウムを 取り込ませたホストーゲスト超分子システムである ${ }^{13)}$ これらは Scheme 2 に示すように, D-A 間の相互作用 による自己会合から始まり, 電子移動, 電荷分離種の生 成, 生成した電荷分離種同士の静電反発による D-Aの 解離と引き続く。その後, 分子の拡散に伴う逆電子移動
が起こり基底状態に戻る。この一連の過程は可逆的であ り，非常にユニークな $\mathrm{D}-\mathrm{A}$ 超分子システムである。こ の系では初期過程の自己会合に関して, 溶媒依存性があ ることも確認されている。また，ナフトクラウンエエーテ ルと芳香族ジイミド体が $\pi-\pi$ スタッキングすることを 利用して, カテナン構造を有する $\mathrm{D}-\mathrm{A}$ 超分子システム も構築されている (Fig. 8) ${ }^{14)}$ 。この超分子システムの 構造に関しては結晶構造解析および ${ }^{1} \mathrm{H}$ NMR スペクト ル解析等により, 芳香族イミドとナフトクラウンエーテ ルが $\pi-\pi$ スタッキングしていることが明らかとなった。 さらに，吸収打よび蛍光スペクトル解析からも D-A 間 に相互作用があることを支持する結果が得られている。

この系で見られる $\pi-\pi$ スタッキングは, カテナン合成 に関してはテンプレートとして働き, 電子移動反応に関 しては D-A 間の分子配向の制御をする。

このように, $\pi-\pi$ スタッキングも電子移動反応に関わ る超分子システムを構筑する上で分子の配向を制御する 重要な分子間相互作用の 1 つであると考えられる。

\section{$2 \cdot 3$ 静電相互作用を利用した電子移動反応}

静電的相互作用を利用した超分子システムの例として

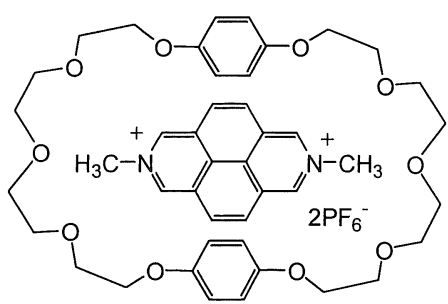

Fig. 7 Structure of the CT Complex between Donor and Acceptor. 

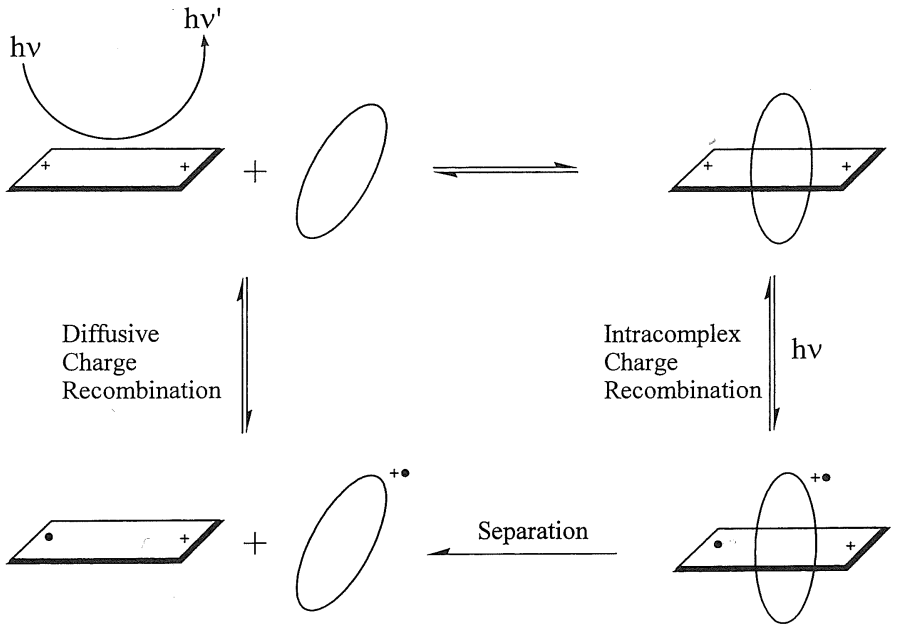

Scheme 2
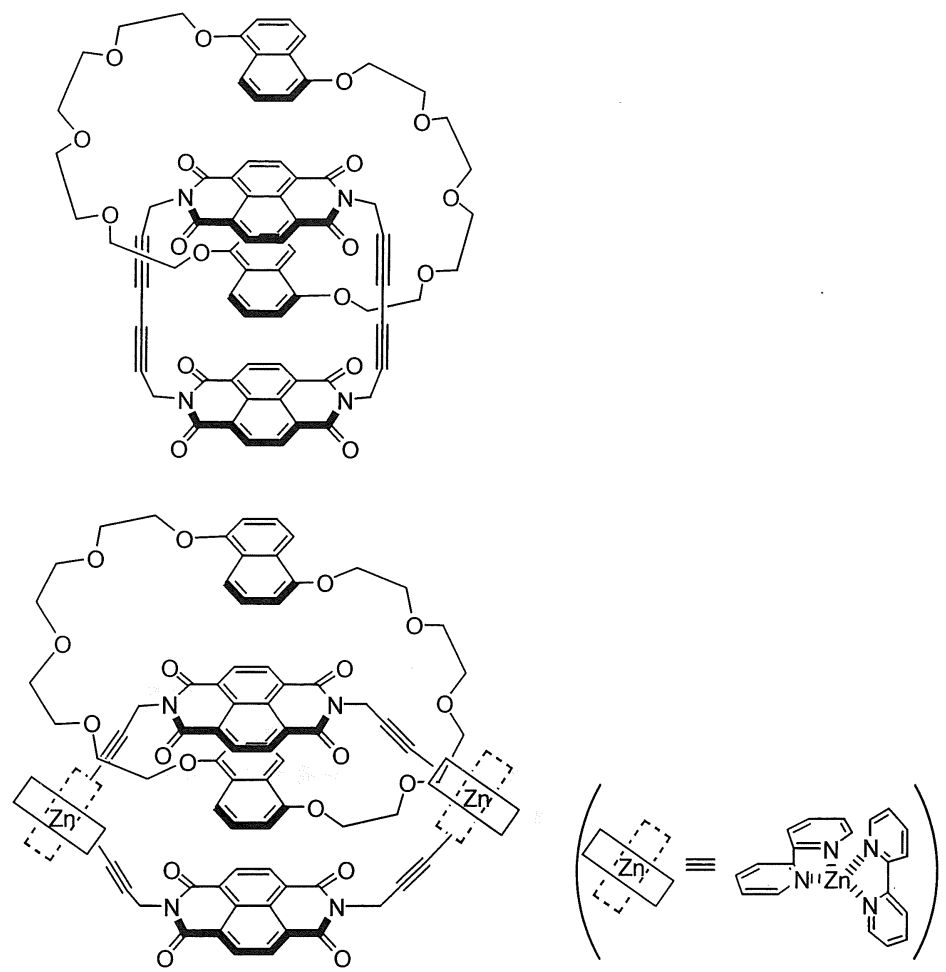

Fig. 8 Two Types of Catenane Assembly from Neutral Donor-Acceptor Building Blocks. 
は，サフィリンとカルボキシレート基を有するポルフィ リンの研究がある15)。この系では, サフィリンがカルボ キシレートアニオンを認識し, 安定な会合体を形成する。 他の例としては, 水溶性のメタロポルフィリンとオリゴ ペプチド系における自己会合型電子移動システム成, メ ソ位にカチオンまたはアニオン性の置換基を有する亜鉛 ポルフィリン同士の静電相互作用を利用した会合体につ いての光誘起電子移動に関する研究 ${ }^{17)}$ などが行われてい る。

\section{$2 \cdot 4$ 水素結合を利用した電子移動反応}

水素結合 1 つの強さは約 $10 \mathrm{~kJ} \mathrm{~mol}^{-1}$ と比較的弱いが, 多点で結合することにより極めて強い相互作用力を示 す。この多点で水素結合する系では, 高い選択性とそれ に由来する配向という大きな特徴が発現される。この水 素結合の特徴は, 超分子構造を形成する場合の重要な因 子となる。生体中ではタンパク質および DNA などの高 次構造（ $\alpha$-ヘリックス, $\beta$-ターン, 二重らせん構造）の 形成への重要な因子として認識されている。また, 水素 結合はプロトン移動などの動的変化を伴うこともある が，この場合においてもプロトンは水素結合の方向に 沿って移動するため, 水素結合の特徴を失うことはない。

Fig. 9 に示した2-および 7-ナフトール基を 4 つのメ ソ位に有するポルフィリンは, 種々のキノンを認識し $\mathrm{D}-\mathrm{A}$ 超分子構造を形成する ${ }^{18)}$ 。このキノン認識能力は キノン分子の構造に大きく依存しており，2,3,5,6,-テ
トラメトキシー $p$-ベンゾキノンを用いた場合に会合定数 が最大であった。これは，キノン分子を認識する際に， メソ位の 4 つの水酸基による多点水素結合が大きく寄与 し, 極めて安定な会合体が形成されるためと結論づけら れている。また，これらの超分子システム中で起こる電 子移動速度は，2-ナフトール基をメソ位に有するポル フィリンの場合（面間距離約 $3.5 \AA$ 只 $k_{\mathrm{CS}}>4 \times 10^{11} \mathrm{~s}^{-1}$, $k_{\mathrm{CR}}>1.1 \times 10^{11} \mathrm{~s}^{-1}$ であったが，一方で $\mathrm{D}-\mathrm{A}$ 間の距離が $6.0 \AA$ と 2 倍程度になるメソ位が 7 -ナフトール基の場合 では $k_{\mathrm{CS}}>4 \times 10^{11} \mathrm{~s}^{-1}, k_{\mathrm{CR}}>6.8 \times 10^{10} \mathrm{~s}^{-1}$ と見積もられ， Staab らが報告している共有結合でリンクしたポルフィ リンーキノン系 ${ }^{19)}$ のものとほぼ同等であった。この超分 子システムでは face-to-face で電子移動が起こるため, 電子移動反応に直接的に水素結合は関与していないと考 えられる。すなわち，水素結合は分子認識にのみ作用す ると結論される。同様な分子認識に水素結合を用いた超 分子システムの電子移動の研究としては，4つのメソ位 に2-ヒドロキシノニル基を有する系 ${ }^{20)}$ ，およびミオグ ロビンに亜鉛ポルフィリンを固定した系 ${ }^{21)}$ の電子移動反 応がある。このように, 水素結合を主に分子認識過程に 用いた一連の超分子システムの電子移動反応に関して は, 幾つかの総説が報告されているのでそちらを参照さ れたい222。

次に，水素結合が直接電子移動反応に関与することに より, 電子移動が加速されるという考え方を検証するた
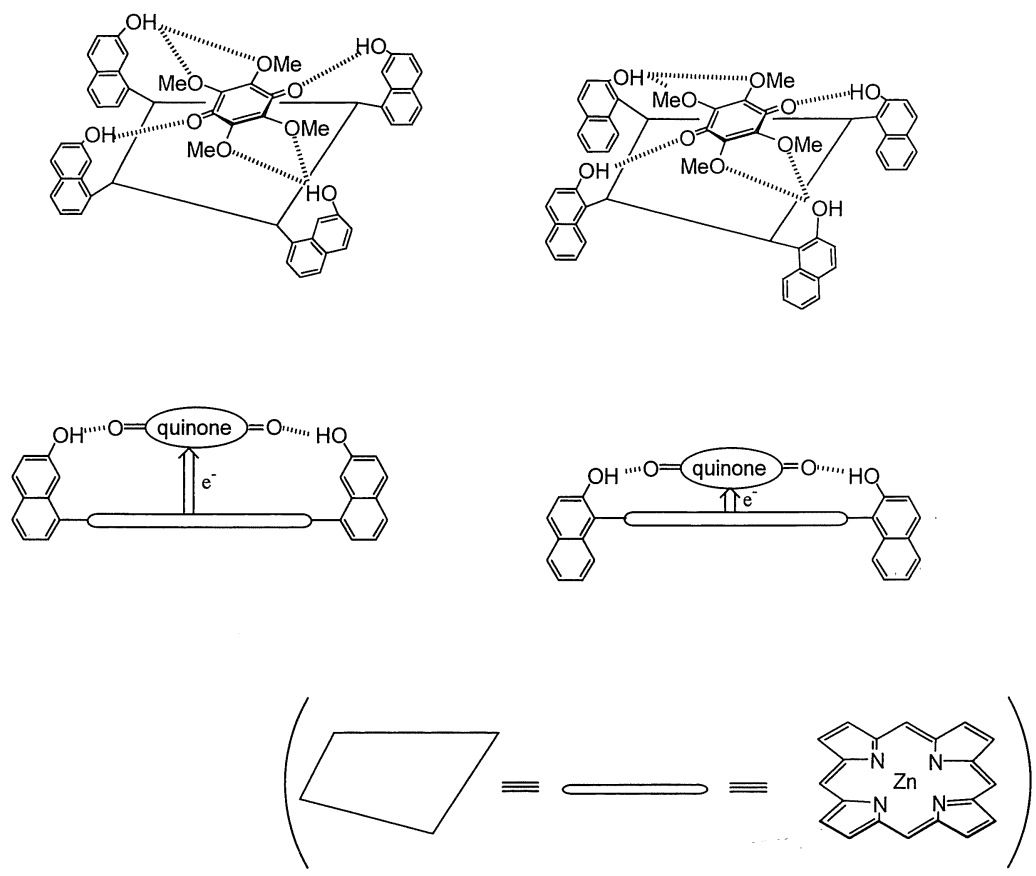

Fig. 9 Schematic Representation of Zn-porphyrin Complex with Quinone. 

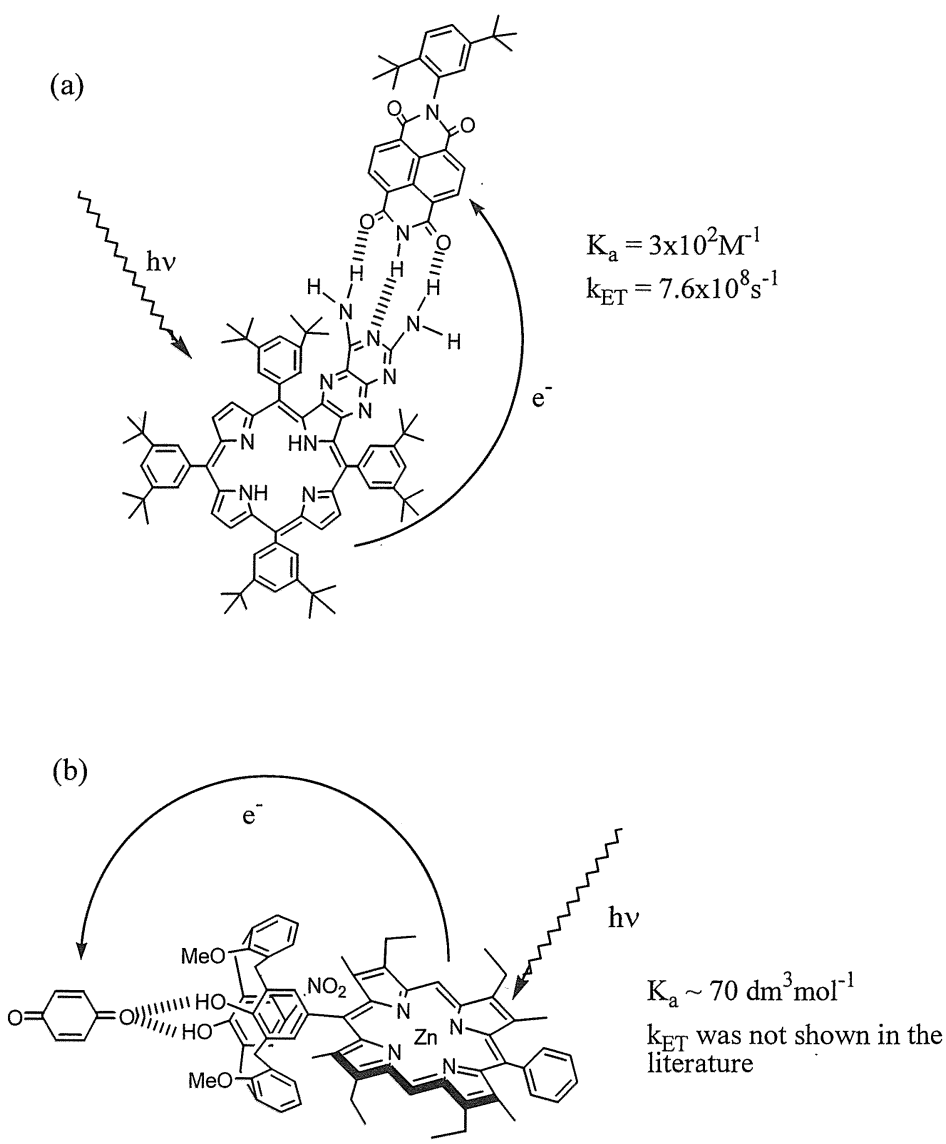

Fig. 10 Structures of Hydrogen Bonded Assembly.

めに分子設計された超分子システムについて述べる。

Fig. 10 にはクロリンーナフタレンジイミド系 $(\mathrm{a})^{23)}$ お よびカリックスアレーンに結合したポルフィリンーキノ ン系 $(\mathrm{b})^{24)}$ の超分子システムの会合定数, 電子移動速度 をそれぞれ示す。これらの超分子システムで起こる電子 移動は，いずれも水素結合を介していると考えられ，極 めて高速で進行することが示唆されている。しかしなが ら，このシステムでの逆電子移動反応も速く，電荷分離 種の直接観測までには至っていない。筆者らは，速い逆 電子移動反応を抑制し電荷分離種の長寿命化を目的とし た多元系の D-A 超分子システムについても検討してい $ろ^{25)}$ 。

電子移動に対する水素結合の加速効果を直接的に検討 するために Therien らは, Fig. 11 に示す超分子システ ム中での電子移動反応について考察している ${ }^{26)}$ 。この系 は，D-A 間をつなぐ結合として水素結合， $\sigma$ 結合およ び $\pi$ 結合を選択し，D-A 間の空間的な位置，結合距離 およびボンド数をほぼ同じにしてある。そのため, 電子 移動速度の差は D-A 間の結合様式の違いに直接反映す
ると考えられ, 電子移動に対する水素結合の効果につい て直接評価できる。その結果, 電子移動速度 $\left(k_{\mathrm{ET}}\right)$ は 結合様式が水素結合， $\sigma$ 結合および $\pi$ 結合の場合にそれ ぞれ 8.1，4.3，8.8× $10^{9} \mathrm{~s}^{-1}$ と見積もられ， $\sigma$ 結合に比 較して水素結合および $\pi$ 結合は電子移動を加速する効 果がみられた。彼らは，この結合様式の違いが電子移動 速度に及ぼす影響について下に示した（1）式から考察 し, 核振動因子 $\left(\nu_{\mathrm{N}}\right)$ やエネルギー項 $\left(\kappa_{\mathrm{N}}\right)$ ではなく電

$$
k_{\mathrm{ET}}=\nu_{\mathrm{N}} \kappa_{\mathrm{E}} \kappa_{\mathrm{N}}
$$

$\nu_{\mathrm{N}} ;$ 核振動因子

$\kappa_{\mathrm{E}} ; \mathrm{D}-\mathrm{A}$ 間の電子カップリング (トンネリングバ リアの高さ）を記述した項

$\kappa_{\mathrm{N}} ;$ 反応の自由エネルギー変化に関連する項

$$
\left(\kappa_{\mathrm{N}}=\left(\exp \left[-\left(\Delta G^{0}+\lambda\right)^{2} / 4 \lambda k \mathrm{~T}\right]\right)\right.
$$

子カップリング $\left(\kappa_{\mathrm{E}}\right)$ が効くためと結論した。これは, D-A 間の電子カップリング効果が電子移動に対して極 めて重要なため, 水素結合により電子移動反応は加速さ れると考えられる。

Therien らの結果を受けて，生体系を意識したアミノ 

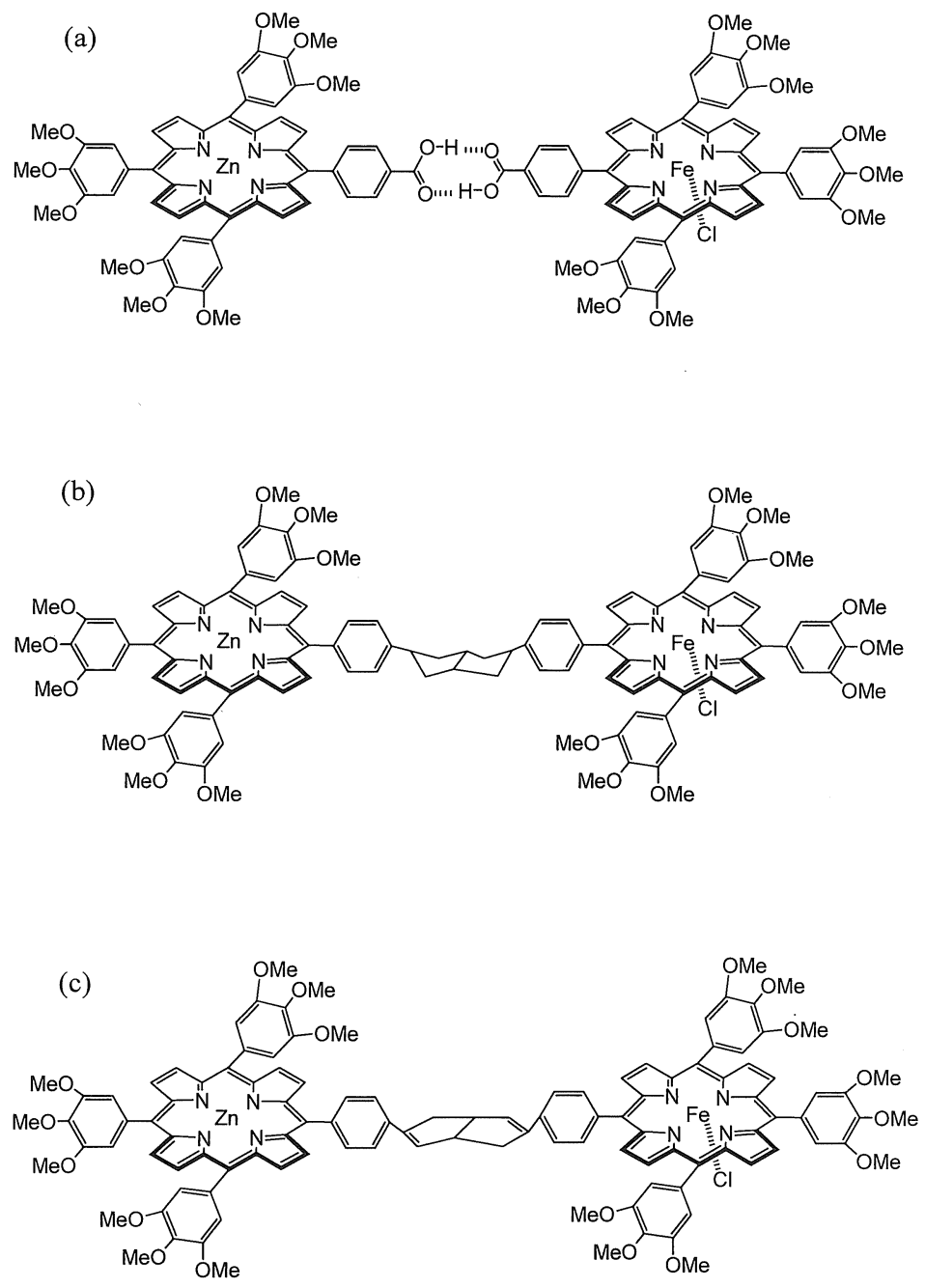

Fig. 11 Three Types of Donor-Acceptor Ensemble Linked by Hydrogen bond (a) ; $\sigma$-bond (b) ; $\pi$-bond (c).

酸残基を用いたペプチドモデルシステム中での電子移動 に関して Fig. 12 の超分子システムが検討されたが27), 水素結合を介した特徴的な電子移動反応過程は観測され ていない。

Fig. 13 に示す D-A システムは，水素結合を介するこ とにより電子移動反応の若干の加速効果がみられた興味 深い分子である28)。この D-A システムは分子内水素結 合によって $\beta$-ターン構造を形成し，水素結合を介した 電子移動可能な分子であり, その電子移動速度は, $\beta$-ター ン構造がほとんど形成されないジメチルスルホキシド中 では $k_{\mathrm{ET}}=3.5 \times 10^{8} \mathrm{~s}^{-1}$ であるのに対し， $80 \%$ 程度の割 合で $\beta$-ターン構造が形成されているジクロロメタン中 では, $1.1 \times 10^{9} \mathrm{~s}^{-1}$ と 4 倍程度の加速効果が見られた。
この加速効果は, 分子内水素結合を介した電子移動過程 によるものと考元られる。同様な加速効果は Tamiaki らによっても報告されている299。

亜鉛ポルフィリンとナフタレンジイミドを水素結合打 よび共有結合で結合させた二つの D-A システムを Fig. 14 に示す30)。ベンゼン中に扔ける水素結合を介した電 子移動速度は $k_{\mathrm{CS}}=4.1 \times 10^{10} \mathrm{~s}^{-1}, k_{\mathrm{CR}}=3.7 \times 10^{9} \mathrm{~s}^{-1}$ と 見積もられ，これに対して共有結合型の值は， $k_{\mathrm{cs}}=9.9$ $\times 10^{10} \mathrm{~s}^{-1}, k_{\mathrm{CR}}=6.7 \times 10^{8} \mathrm{~s}^{-1}$ であった。この二つの系 ではその電子移動速度はほぼ同程度であり, 水素結合を 介することによる電子移動速度の有為な差異は発現され なかった。しかしながら，この系では $k_{\mathrm{H}} / k_{\mathrm{D}}=1.4$ およ び 1.5 と同位体効果が見られたことから，プロトン移動 


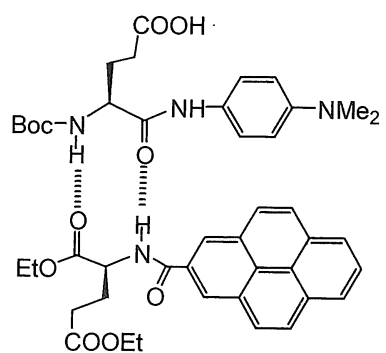

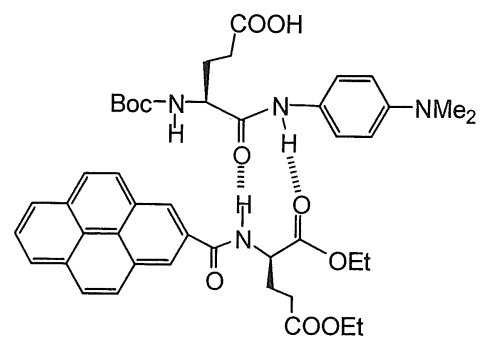

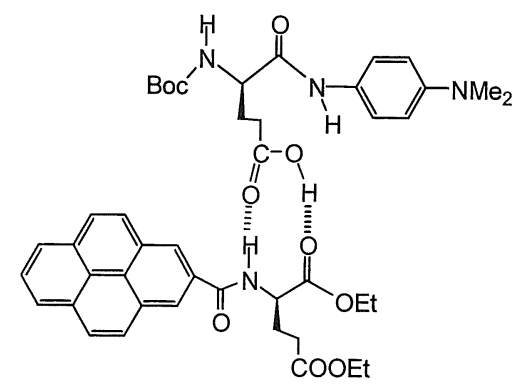

Fig. 12 Possible Structures of Donor-Acceptor Assembly Linked by Hydrogen Bond.

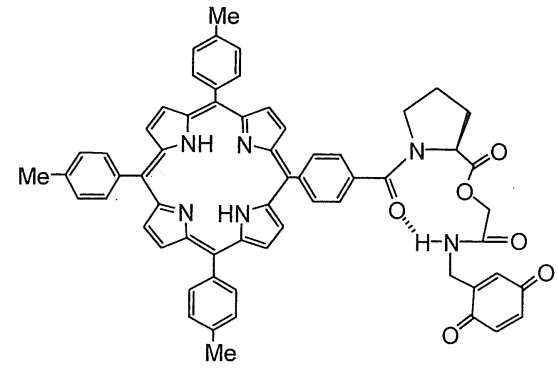

Fig. 13 Structure of Porphyrin-quinone Compound Having $\beta$-form Structure.

が関与した電子移動が起こっていると考えられ，プロト ン移動をも含めた電子移動過程を考慮する必要がある。 プロトン移動を伴う電子移動は, 生体内でのエネル ギー生産に関わる多くのタンパク質や酵素において見ら れる電子移動過程で, 光誘起電子移動反応に伴いプロト ンが輸送されて光エネルギーから化学エネルギーへの変 換が行われる。このように，プロトン移動を伴う電子移 動過程はエネルギー変換機構との関係で, 極めて重要な 電子移動過程の 1 つとして認識されている。このプロト ン移動を伴う電子移動に関しては, Nocera らにより電 子移動と共にプロトン移動可能なインターフェイスを有 する D-A 超分子システムを用いて検討されている31。 彼らは，プロトン移動を伴う電子移動では，プロトン移 動により D-A 間の電荷の再配置が起こり，それにつづ く溶媒和の変化に伴う活性化エネルギーの障壁が電子移 動速度を低下させると結論している。さらに, 彼らは Fig. 15 に示すような D-A 間のインターフェイスを交換 したような超分子システムを詳細に検討し，同様な結論 を導いている ${ }^{32)}$ 。最近では，プロトン移動と電子移動と

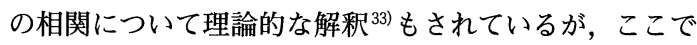

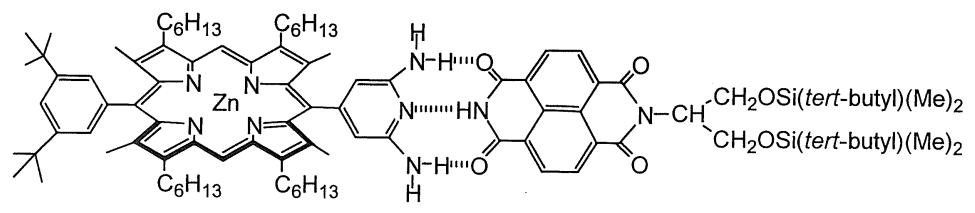

Supramolecular assembly

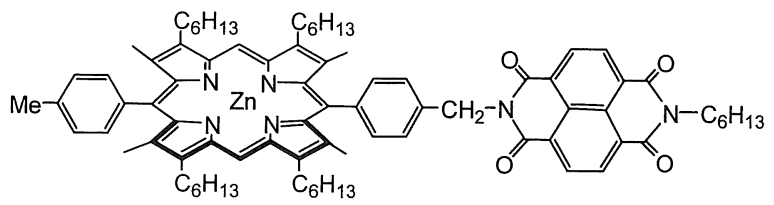

Fig. 14 Structures of Hydrogen Bonded Assembly (above) and Its Reference Compound (below). 

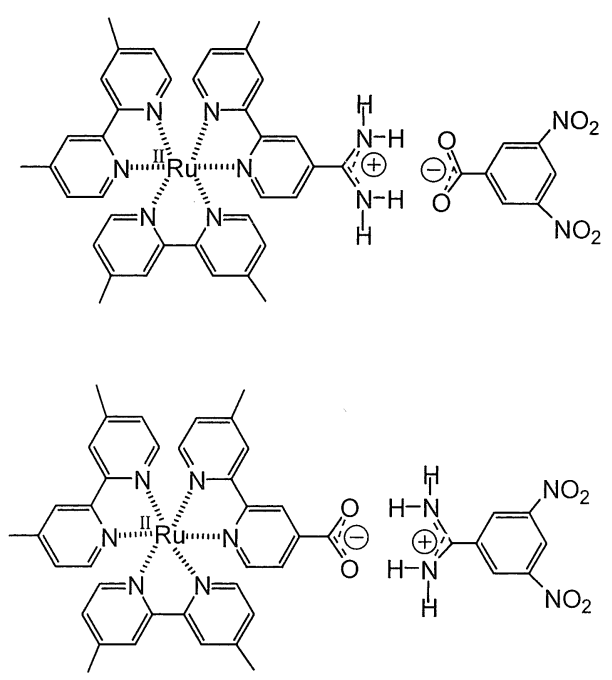

Fig. 15 Supramolecular Assemblies Juxtaposed by Salt Bridge.

は割愛させていただく。

$$
\begin{gathered}
2 \cdot 5 \text { 複数の分子間相互作用によって形成される超分 } \\
\text { 子システム }
\end{gathered}
$$

Fig. 16 は，ポルフィリン中心金属へのピリジンの軸 配位性と，アミドプロトンーキノン分子間に生じる水素 結合による相互作用を巧みに利用し, 極めて複雑に設計 された 3 成分からなる $\mathrm{D}-\mathrm{A}$ 超分子システムを示してい る34)。この超分子システムでは, ホスト分子へのキノン の取り込みに対する会合定数はクロロホルム中で $3 \times$ $10^{3} \mathrm{dm}^{3} \mathrm{~mol}^{-1}$ 程度，ピリジル基の中心金属への結合定数 は塩化メチレン中で $3.2 \times 10^{2} \mathrm{dm}^{3} \mathrm{~mol}^{-1}$ と見積もられ た。また，蛍光スペクトル測定では，キノン分子による ポルフィリンの蛍光消光も観測された（Fig. 16）。

\section{3 おわりに}

生体中のクロモフォアが形成する超分子構造は複数の 分子間相互作用によって組織化されていることを考える と, 今後は 2.5 に示したような複数の異なった非共有結 合を用いて構築された超分子システム中の電子移動につ いての詳しい検討が必要になる。現状では水素結合の効 果については幾らかの予測ができる程度にまでは至って いるが，まだまだ議論の余地を残しており，完全に統一 的な解勫ができたとは言い難い。今後は，電子移動反応 に対する非共有結合の果たす役割をより詳細に検討する ために，精密な分子設計のもと，高度な有機合成的手法 を用いて分子配向が精緻に制御された超分子の「ものつ くり」が望まれる。

(受付： 2000 年 6 月 27 日, 受理 : 2000 年 7 月 12 日)

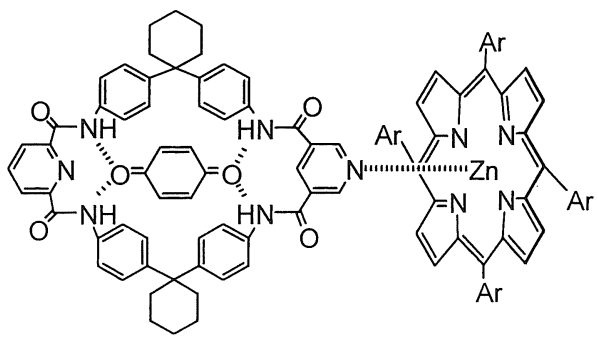

Fig. 16 Ternary Assembly Consisting of Hydrogen Bond and Coordination Bond.

\section{文献}

1）坂田祥光，有機合成化学協会誌，39，909 (1981); H. Kurreck, M. Huber, Angew. Chem. Int. Ed. Eng., 34, 849 (1995).

2) A. Osuka, S. Nakajima, T. Okada, S. Taniguchi, K. Nozaki, T. Ohno, I. Yamazaki, Y. Nishimura, N. Mataga, Angew. Chem. Int. Ed. Eng., 35, 92 (1996).

3) J.-M. Lehn, Angew. Chem. Int. Ed. Eng., 27, 90 (1988) ; D. Philip, J.F. Stoddart, Angew. Chem. Int. Ed. Eng., 35, 1154 (1996).

4) 有村隆志, 有機合成化学協会誌，55，557 (1997); M.D. Ward, Chem. Soc. Rev., 26, 365 (1997).

5) A. Harriman, F. Odobel, J.-P. Sauvage, J. Am. Chem. Soc., 117, 9461 (1995) ; J.-P. Collin, P. Gavina, V. Heitz, J.-P. Sauvage, Eur. J. Inorg. Chem., 1, 1998 ; J.-C. Chambron, J.-P. Collin, J.O. Dalbavie, C.O. Dietrich-Buchecker, V. Heitz, F. Odobel, N. Solladie, J.-P. Sauvage, Coord. Chem. Rev., 178-180, 1299 (1998).

6) M. Ohkohchi, A. Takahashi, N. Mataga, T. Okada, A. Osuka, H. Yamada, K. Maruyama, J. Am. Chem. Soc., 115, 12137 (1993) ; K. Maruyama, A. Osuka, N. Mataga, Pure Appl. Chem., 65, 867 (1994) ; D. Gust, T.A. Moore, A.L. Moore, S.-J. Lee, E. Bittersmann, D.K. Luttrull, A.A. Rehms, J.M. Degraziano, X.C. Ma, F. Gao, R.E. Belford, T.T. Trier, Science, 248, 199 (1990).

7) L. Flamigni, F. Barigelletti, N. Armaroli, J.-P. Collin, I.M. Dixon, J.-P. Sauvage, J.A.G. Williams, Coord. Chem. Rev., 190-192, 671 (1999) ; L. Flamigni, F. Barigelletti, N. Armaroli, B. Ventura, J.-P. Collin, J.-P. Sauvage, J.A.G. Williams, Inog. Chem., 38, 661 (1999).

8) N. Armaroli, F. Diederich, C.O. Dietrich-Buchecker, L. Flamigni, G. Marconi, J.F. Nierengarten, J.P. Sauvage, Chem. -Eur. J., 4, 406 (1998) ; L. Flamigni, F. Barigelletti, N. Armaroli, J.-P. Collin, J.-P. Sauvage, J.A.G. Williams, Chem. -Eur. J., 4, 1744 (1998) ; J.-C. Chambron, J.-P. Collin, J.-O. Dalbavie, C.O. Dietrich-Buchecker, V. Heitz, F. 
Odobel, N. Solladie, J.-P. Sauvage, Coord. Chem. Rev., 178-180, 1299 (1998).

9) D.B. Amabilino, J.-P. Sauvage, Chem. Commun., 2441, 1996 ; M. Linke, J.-C. Chambron, V. Heitz, J.-P. Sauvage, J. Am. Chem. Soc., 119, 11329 (1997) ; M. Linke, J.-C. Chambron, V. Heitz, J.-P. Sauvage, V. Semetey, Chem. Commun., 2469, 1998 ; D.B. Amabilino, J.-P. Sauvage, New. J. Chem., 22, 395 (1998) ; J.-C. Chambron, J.P. Sauvage, Chem. -Eur. J., 4, 1362 (1998) ; M.-J. Blanco, M.C. Jimenez, J.-C. Chambron, V. Heitz, M. Linke, J.P. Sauvage, Chem. Soc. Rev., 28, 293 (1999).

10) T.D. Ros, M. Prato, D. Guldi, E. Alessio, M. Ruzzi, L. Pasimeni, Chem. Commun., 635, 1999.

11) C.A. Hunter, R.K. Hyde, Angew. Chem. Int. Ed. Engl., 35, 1936 (1996).

12) H. Imahori, E. Yoshizawa, K. Yamada, K. Hagiwara, T. Okada, Y. Sakata, J. Chem. Soc., Chem. Commun., 1133, 1995 ; H. Imahori, K. Yamada, E. Yoshizawa, K. Hagiwara, T. Okada, Y. Sakata, J. Porphirins Phthalocyanines, 1, 55 (1997) ; K. Yamada, H. Imahori, E. Yoshizawa, D. Gosztola, M.R. Wasielewski, Y. Sakata, Chem. Lett., 235, 1999.

13) A.C. Benniston, A. Harriman, D.S. Yufit, Angew. Chem. Int. Ed. Engl., 36, 2356 (1997).

14) D.G. Hamilton, J.K.M. Sanders, J.E. Davies, W. Clegg, S.J. Teat, Chem. Commun., 897, 1997 ; A.C. Try, M.M. Harding, D.G. Hamilton, J.K.M. Sanders, Chem. Commun., 723, 1998 ; D.G. Hamilton, J.E. Davies, L. Prodi, J.K.M. Sanders, Chem. Eur. J., 4, 608 (1998) ; Q. Zhang, D.G. Hamilton, N. Feeder, S.J. Teat, J.M. Goodman, J.K.M. Sanders, New J. Chem., 23, 897 (1999).

15) S.L. Springs, D. Gosztola, M.R. Wasielewski, V. Kral, A. Andrievsky, J.L. Sessler, J. Am. Chem. Soc., 121, 2281 (1999).

16) M. Aoudia, M.A.J. Rodgers, J. Am. Chem. Soc., 119, 12859 (1997).

17) D.J. Fermin, H.D. Duong, Z. Ding, P.-F. Brevet, H.H. Girault, J. Am. Chem. Soc., 121, 10203 (1999).

18) T. Hayashi, T. Miyahara, N. Hashizumi, H. Ogoshi, J. Am. Chem. Soc., 115, 2049 (1993); T. Hayashi, T. Miyahara, Y. Aoyama, M. Noguchi, H. Ogoshi, Chem. Lett., 1749, 1994 ; T. Hayashi, T. Miyahara, S. Kumazaki, H. Ogoshi, K. Yoshihara, Angew. Chem. Int. Ed. Engl., 35, 1964 (1996).

19) H. Heitele, F. Pöllinger, T. Häberle, M.E. Michel-
Beyerle, H.A. Staab, J. Phys. Chem., 98, 7402 (1994).

20) T. Hayashi, T. Asai, F. M. Borgmeier, H. Hakazono, H. Ogoshi, Chem.-Eur. J., 4, 1266 (1998).

21) T. Hayashi, A. Tomokuni, T. Mizutani, Y. Hisaeda, H. Ogoshi, Chem.Lett., 1229, 1998 ; T. Hayashi, Y. Hitomi, T. Ando, T. Mizutani, Y. Hisaeda, S. Kitagawa, H. Ogoshi, J. Am. Chem. Soc., 121, 7747 (1999) ; Y.-Z. Hu, S. Tsukiji, S. Shinkai, I. Hamachi, Chem.Lett., 517, 1999.

22) T. Hayashi, H. Ogoshi, Chem.Soc. Rev., 26, 355 (1997); 林 高史, 有機合成化学会誌, 56, 745 (1998).

23) J.L. Sessler, C.T. Brown, D. O'Connor, S.L. Springs, R. Wang, M. Sathiosatham, T. Hirose, $J$. Org. Chem., 63, 7370 (1998).

24) T. Arimura, S. Ide, H. Sugihara, S. Murata, J.L. Sessler, New J. Chem., 23, 977 (1999).

25) T. Arimura, S. Ide, T. Nishioka, H. Sugihara, S. Murata, T. Yamato, J. Chem. Res., 印刷中; T. Arimura, Y. Suga, K. Jacob, H. Sugihara, S. Murata, H. Tsuzuki, Synthesis, 印刷中.

26) P.J.F. de Rege, S.A. Williams, M.J. Therien, Science, 269, 1409 (1995).

27) S. Aich, H.B. Kraatz, J. Chem. Soc., Perkin Trans. 2, 301, 1999.

28) D.A. Williamson, B.E. Bowler, J. Am. Chem. Soc., 120, 10902 (1998).

29) H. Tamiaki, K. Maruyama, Chem. Lett., 1499, 1993.

30) A. Osuka, R. Yoneshima, H. Shiratori, T. Okada, S. Taniguchi, N. Mataga, Chem. Commun., 1567, 1998.

31) J.A. Roberts, J.P. Kirby, D.G. Nocera, J. Am. Chem. Soc., 117, 8051 (1995) ; J.P. Kirby, N.A. van Dantzig, C.K. Chang, D.G. Nocera, Tetrahedron Lett., 36, 3477 (1995).

32) J.P. Kirby, J.A. Roberts, D.G. Nocera, J. Am. Chem. Soc., 119, 9230 (1997) ; Y. Deng, J.A. Rberts, S.-M. Peng, C.K. Chang, D.G. Nocera, Angew. Chem. Int. Ed. Engl., 36, 2124 (1997).

33) R.I. Cukier, D.G. Nocera, Annu. Rev. Phys. Chem., 49, pp.337-369 (1998); A. Soudackov, S. Hammes-Schiffer, J. Am. Chem. Soc., 121, 10598 (1999).

34) C.A. Hunter, R. Shannon, Chem. Commun., 1361, 1996. 


\title{
日本油化学会誌本号掲載＼cjkstart論文要旨
}

\section{[総説］＼cjkstart非共有結合型光誘起電子移動研究の新展開}

\author{
須 賀 康 裕 ・ 有 村 隆 志 \\ 工業技術院 物質工学工業技術研究所 $\mathrm{COE}$ 特別研究室 \\ （テ305-8565＼cjkstart茨城県つくば市東 1-1）
}

生体系での高効率な光誘起電子移動反応を解明するために, 電子ドナー (D) と電子アクセプター (A) とを共有 結合で固定したモデル研究が行われてきた。しかしながら, 生体中の電子移動システムは, 複数の比較的弱い分 子間相互作用により配置されたクロモフォア群から構成されている。このことを考慮して, 最近では電子移動反 応に対する分子間相互作用の役割の重要性が指摘されており, 超分子システム中での電子移動反応の研究が盛ん に行われている。本稿では，配位結合， $\pi-\pi$ スタッキング，静電相互作用，水素結合を用いて， D-A 間の距離 や分子配向を精緻に制御した超分子システム中で起こる電子移動反応についての最近の研究例を紹介し, 今後の 展開について考察する。

(連絡者：有村隆志） Vol.49, No.9, 893 (2000)

\section{[総説］＼cjkstart炎症誘発因子としての血小板活性化因子}

\author{
唐 沢 健 \\ 帝京大学薬学部薬品物理化学教室 \\ （テ199-0195＼cjkstart神奈川県津久井郡相模湖町寸沢嵐 1091）
}

血小板活性化因子 (Platelet-activating Factor; PAF) は細胞膜リン脂質を前駆体として生成する内因性のリン脂 質である。PAF は抗原感作したウサギ好塩基球より放出され血小板を凝集させる液性因子として，1972 年に Benvenisteによって発見された。1979 年にPAF の構造が 1-O-アルキル-2-アセチル-sn-グリセロ-3-ホスホコ リンと同定されて以来，PAF は血小板活性化作用以外にも血管透化性元進，白血球活性化，平滑筋収縮などの 炎症反応に関与する生理活性を持つことが明らかとされてきた。一方, 天然物や合成 PAFアナログから抗 PAF 薬の探索が行われ，数多くの PAF の受容体に作用するアンタゴニストが報告された。PAFアンタゴニストの存 在はPAF が標的器官上のレセプターを介して作用することを示しており，1991 年に至って，Shimizu らにより PAF 受容体の遺伝子が初めて単離された。一方, PAF の分解・不活化酵素である PAF-アセチルハイドロラー ゼの遺伝的欠損が Miwa（3）らによって 1988 年に報告された事を契機として，この酵素の気管支喘息を代表とす るアレルギー性疾患への関与について急速に関心が高まり, 細胞内型酵素の遺伝子クローニングが 1994 年に (4), また，血漿型酵素については 1995 年に報告がなされた(5)。PAF 受容体㧍よびPAF アセチルハイドロラーゼの 遺伝子が単離された事により，炎症反応における PAFの作用メカニズムおよび病態における役割に関する研究 において飛躍的な進展が見られ，本稿では，主としてこれらについて記述した。

（連絡者：唐沢 健） Vol.49, No.9, 905 (2000) 